\section{Provenance of archaeological wool textiles: new case studies}

Karin M. Frei

The National Museum of Denmark, The National Research Foundation's Centre for Textile Research, Copenhagen, Denmark

\section{Abstract}

In the last two decades, measurements of strontium ( $\mathrm{Sr}$ ) isotopes in archaeological bone tissues/skeletons have shown to be an effective technique for the characterisation of human and animal mobility in prehistory. More recently, this tracing system is also being applied to the investigation of archaeological textile's provenance. The importance of ancient textiles has been often underestimated, however research of archaeological textiles is currently experiencing an extremely increasing interest as the development of new methodologies, conducting experimental studies and lancing of new projects are providing an unreached amount of new information, knowledge and impressive data sets which together build the basis of novel thinking and interpretations. This manuscript aims at summarising two of the most recently developed methods that focus on the extraction of Sr from ancient non-dyed and organic-dyed wool threads from archaeological textiles in an attempt to identify if the raw materials are local or non-local to the sites. In particular, this study presents two case studies which rely on the use of these chemical protocols. The first example deals with a woolfur sample from a modern Greenlandic Musk ox. The purpose of this study is to characterise wool from an exotic animal on the one side, and to try to establish a link between this wool and a geologically-seen ancient and very special terrain (Archaean basement rocks from the Kangerlussuaq area of Western Greenland) on which this musk ox was grazing. Our interest was focused on whether the bioavailable Sr fraction from this terrain impacted on the composition of the wool from the animal. The second case study deals with three thread samples from four ancient wool textile pieces recovered from one and the same pre-Roman Iron Age peat bog site at Krogens Mølle (Denmark). Some of these textiles have proven to be dyed with organic dyestuffs. This study therefore aimed at applying a novel pre-cleaning methodology developed for dyed (by organic dyestuffs) wool threads from ancient textiles. The outcome of these two particular studies revealed both the potential of these novel methodologies for retrieving the original Sr isotope signature of the raw material wool, and their limitations.

\section{Introduction}

Ericson (1985) was the first who proposed the idea of using the variations of the strontium (Sr) isotopic ratios in archaeological materials and to relate these to the bedrock and soil characteristics of specific geological areas and thus to constrain their potential geographical origin. Since then, many studies of human and animal migration have been conducted on the base of archaeological bone tissue/skeletons (Evans et al., 2006; Grupe et al., 1997; Knudson et al., 2005; Montgomery et al., 2003; Price et al., 1998, 2010, 2011). The base for performing such tracing studies lies in the fact that $\mathrm{Sr}$ isotopic ratios $\left({ }^{87} \mathrm{Sr} /{ }^{86} \mathrm{Sr}\right)$ do not change within their pathway throughout the food chain (Graustein, 1989). Furthermore, the age and the type of lithology of the bedrocks (magmatic, metamorphic and sedimentary rocks) on which respective soils are developed impose a control on the ${ }^{87} \mathrm{Sr} /{ }^{86} \mathrm{Sr}$ ratios of a particular geological area and thereby creating necessary variations in this signature which are measurable and traceable. However, studies have shown that the knowledge of the local bedrock is not always sufficient; hence there is the need to characterise the so-called bio-available $\mathrm{Sr}$ isotope composition of the targeted area. There are several ways to characterise such a bio-available signature: by bone tissue of small animals, by plants, by water and/or soil samples (Evans et al., 2010; Frei and Frei, 2011; Price et al., 2002). However, it should be noted that the spatial resolution of the bio-available ${ }^{87} \mathrm{Sr} /{ }^{86} \mathrm{Sr}$ ratios can be similar in different geographical areas, therefore setting limits to the discrimination between different areas with the same or very similar bio-available $\mathrm{Sr}$ characteristics. Several book chapters and review articles have recently been written on the subject of the application of Sr isotopes to study human and animal migration, thus this manuscript will concentrate on the novel methods developed for applying this tracing system to ancient wool and refers to the following articles in which more information regarding the parameters controlling the $\mathrm{Sr}$ isotopic system are contained (Bentley, 2006; Montgomery, 2010; Price and Burton, 2011; Price et al., 2002).

Wool textiles, and hence the raw material wool, are often regarded as rare finds in archaeological contexts. Nevertheless, there are a number of notable exceptions. For example, in northern Europe, and most specifically in Denmark, there is an assemblage of extremely well preserved pre-Roman Iron Age textile finds recovered from peat bogs and contained in oak coffins from Bronze Age graves. These finds comprise a rich variety of garments (Andersson Strand et al., 2010; Bender Jørgensen, 1986; Broholm and Hald, 1940;
Correspondence: Karin M. Frei, The National Museum of Denmark, The National Research Foundation's Centre for Textile Research, Prinsens Palae, Frederiksholms Kanal 12, 1220 Copenhagen, Denmark.

Tel.Fax: +45.33134411

E-mail: Karin.M.Frei@natmus.dk

Key words: textiles, strontium isotopes, provenance, Iron Age, Krogens Mølle.

Acknowledgments: I would like to thank Ulla Mannering and Irene Skals both from the National Museum of Denmark (NMD) for their advice and help sampling the ancient textile threads. I would also want to show my appreciation to Poul Otto Nielsen (NMD) who has provided me access to the textile collections, to Robert Frei who has provided me access to the laboratories of the Danish Center of Isotope Geology at the Geographical and Geological Institute of Copenhagen University, as well as Marie Louise Nosch and Eva Andersson Strand for their support within my research. Alicia E. Dick is thanked to have sampled the Musk ox wool in Greenland and Cristina Olsen for help in the lab. The research leading to these results has received fundings from the Danish National Research Foundation DNRF 64

Citation: Frei KM, 2014. Provenance of archaeological wool textiles: new case studies. In: RH Tykot (ed.), Proceedings of the $38^{\text {th }}$ International Symposium on Archaeometry - May $10^{\text {th }}-14^{\text {th }}$ 2010, Tampa, Florida. Open Journal of Archaeometry 2:5239.

Presented at the $38^{\text {th }}$ International Symposium on Archaeometry - May $10^{\text {th }}-14^{\text {th }} 2010$, Tampa, Florida.

This work is licensed under a Creative Commons Attribution 3.0 License (by-nc 3.0).

(C) Copyright K.M. Frei, 2014

Licensee PAGEPress, Italy

Open Journal of Archaeometry 2014; 2:5239

doi:10.4081/arc.2014.5239

Brøndsted, 1960). In case of the peat bog finds, these textiles have been preserved due to the acidic conditions present in their burial contexts. The importance of ancient textiles, such as garments, blankets, floor-mats or even sails, has been somewhat underestimated within the archaeological world (Gleba, 2008). However, textile research is today a growing field within archaeology, proving to be an important source of information for prehistoric societies. Moreover, textile production is a craft that needs meticulous planning and the crafts people must have possessed many different skills and a priori know-how. In Northern and Central Europe, the Mediterranean and the Near East the most common fibre materials were animal fibres from sheep and goats as well as plant fibres from flax, hemp and nettle 
(Barber, 1991). Despite the increasing interest in archaeological textiles, one of the most important questions, namely the one of provenance, remains often unclear, as only comparative studies were possible. However, there have been a few attempts to fill this gap both for plant and animal fibres (Benson et al., 2006; Frei, 2009; Frei et al., 2009b; Von CarnapBornheim et al., 2007).

\section{Case Studies}

Modern unspun wool fibers from Greenlandic Musk ox were collected during the summer 2009 in the western Greenlandic town of Kangerlussuaq (Sønderstrømfjord) in an area close to the inland ice sheet. Most of the native population of Musk ox in Greenland originally stems from the northeastern part of Greenland, and individual animals were moved to other parts of Greenland later on, so to the area around Kangerlussuaq. Musk ox feed on willow and various grasses. Musk ox fur consists of two layers, an inside part composed of fleece (which is the actual wool) and an outer part which consists of extremely long hair. The fleece naturally faals during the summer period, where people usually collect it to produce a very soft yarn. The sample analysed in this study was collected in a similar way. The wool was neither treated nor cleaned in any way prior the pre-cleaning methods described in the analytical techniques section. The wool had a natural brownish pigmentation colour.

The ancient samples consisted of four yarn pieces all unearthed from the same Danish peat bog near Krogens Mølle and belong to the Danish pre-Roman Iron Age (500 BC-AD 1; National Museum of Denmark nr D 1310). The research leading to these results has received fundings from the Danish National Research Foundation DNRF 64.Recently some of these textiles have been ${ }^{14} \mathrm{C}$ dated to $399-207 \mathrm{BC}$ (cal) (Mannering et al., 2010). Textiles and skin fragments were discovered in the Krogens Mølle peat bog site located on the northern part of Jutland in 1878. The skins and textiles were found together with some skeletal remains, identified as female (Hald, 1980). The textiles consist of several woven pieces all made of wool. The three textiles specified below were chosen for this study and small thread samples (less than $20 \mathrm{mg}$ ) from each was removed from the respective woven textile pieces.

Sample D 1310 A was collected from a torn off strip with dimensions $40 \times 32 \mathrm{~cm}$. The yarn from which this textile piece is made of is fairly finely spun and woven as a tabby with a checkered pattern. The wool has been identified as sheep wool. From this piece two samples were investigated, one thread from the darker wool and one from the lighter wool.

Sample D 1310 D was collected from a badly damaged textile piece with dimensions 84 x 43 $\mathrm{cm}$ which appears to originally have been part of a bag. It is also made of sheep wool.

Sample D $1310 \mathrm{~J}$ was separated from an irregular strip with a tubular woven selvedge and with dimensions $50 \times 60 \mathrm{~cm}$. Some of the loose ends of this textile piece are tied in knots, apparently done in antiquity.

Recent dye analyses [high performance liquid chromatography (HPLC)] conducted on a wool thread samples belonging to one of the textiles of the Krogens Mølle find (Vanden Berghe et al., 2009) showed that they had been dyed in Antiquity with luteolin-containingdyestuff. Ancient textiles that can be shown to contain organic dyestuff, by e.g. HPLC analyses, need to be specially treated in order to ensure the recovery of the true wool's nutritional information. It is tenable to believe that the threads studied herein from this location were also dyed with an organic dyestuff. Therefore, in this study, we introduced an additional extra pre cleaning step of the sample before its final dissolution, particularly aimed at recovering a dye-free fraction of $\mathrm{Sr}$ from the fibers which then closely approximates the composition of the true bio-available Sr. Therefore, this additional step allows for a dyestuff decontamination of the sample material prior to ion chromatography procedures.

This is important as dyestuff has been shown to potentially mask/contaminate the $\mathrm{Sr}$ isotopic signature of a textile's raw material (Frei et al., 2010). The organic dye-removal step has shown to be able to remove up to $100 \%$ of organic dyestuff without the use of mordants, and up to $99.5 \%$ when mordants have been used.

\section{Materials and Methods}

\section{Pre-cleaning/decontamination}

The unspun wool sample from the Musk ox was washed in $20 \%$ dilute cold hydrofluoric (HF) acid under ultrasonic treatment for $1 \mathrm{~h}$ in a $7 \mathrm{~mL}$ Teflon beaker (Savillex ${ }^{\mathrm{TM}}$; Savillex, Eden Prairie, MN, USA) prior to dissolution.

The hydrofluoric acid wash was subsequently pipettet off from the actual wool sample.

The wool sample was deeply rinsed (several times) with $1 \mathrm{~mL}$ of deionised water $\left(\mathrm{Milli}^{\mathrm{TM}}\right.$; Millipore, Billerica, MA, USA) and dried down.

A $1 \mathrm{~N}$ hydrochloric acid $(\mathrm{HCl})$ wash followed the HF treatment step.

The remaining wool sample was again deeply rinsed (several times) with $1 \mathrm{~mL}$ of deionised water (MilliQ ${ }^{\mathrm{TM}}$; Millipore) and finally dried down.

Two extra pre-cleaning steps no should followed the HF-pre-cleaning step for organic dyed wool.

The rinsed wool sample was emerged in 3 $\mathrm{mL}$ of $0.2 \mathrm{M}$ ammonium peroxodisulfate $\left(\mathrm{NH}_{4}\right)_{2} \mathrm{~S}_{2} \mathrm{O}_{8}$ [a strong oxidant (APDS)] on a hotplate (preferentially at $130^{\circ} \mathrm{C}$ ) for $\mathrm{ca}$. 15-30 min, depending on the degradation of the sample.

The residual wool sample is then deeply rinsed with $1 \mathrm{~mL}$ of deionised water (MilliQ ${ }^{\mathrm{TM}}$; Millipore) several times and subsequently dried down.

\section{Dissolution and ion chromato- graphic procedures}

In order to be able to keep track of the $\mathrm{Sr}$ mass budget during the different pre-cleaning steps applied to the samples, a ${ }^{84} \mathrm{Sr}$ enriched (94\%) spike was added to the respective leachates and to the finally dissolved sample. This provides a measure to also control the concentration of $\mathrm{Sr}$ in the pre-cleaned wool residue, which should be in the range of 0.05 15 ppm usually characteristic of natural animal hair.

The residual wool fraction is dissolved in a 1:1 mixture of $30 \% \quad \mathrm{HNO}_{3}$ (Seastar, Jacksonville, FL, USA) and $30 \% \quad \mathrm{H}_{2} \mathrm{O}_{2}$ (Seastar). The samples tend to decompose within 30 minutes. After decomposition the solution is dried down on a hotplate at $c a$. $80^{\circ} \mathrm{C}$.

Samples are then taken up in a few drops of $3 \mathrm{~N} \mathrm{HNO}_{3}$ and loaded on either glass extraction columns or on disposable pipette-tip columns containing $0.2 \mathrm{~mL}$, intensively pre-cleaned SrSpecTM (Eichrome Inc., Lisle, IL, USA), mesh 50-100 resin. The elution recipe essentially follows that of Horwitz et al. (1992).

The $\mathrm{Sr}$ fraction is eluted by ultra pure deionised water and subsequently dried down on a hotplate. Organic compounds are often retained on the resin, causing a brownish staining of the originally white resin.

\section{Thermal ionisation mass spectrometry}

The samples are dissolved in $2.5 \mu \mathrm{L}$ of a $\mathrm{Ta}_{2} \mathrm{O}_{5}-\mathrm{H}_{3} \mathrm{PO}_{4}-\mathrm{HF}$ activator. The samples are then loaded onto outgassed $99.98 \%$ single rhenium filaments. Samples are measured in socalled dynamic mode on a VG 54 Sector IT mass spectrometer, at temperatures between 1300 and $1450^{\circ} \mathrm{C}$, and keeping the ${ }^{88} \mathrm{Sr}$ signal at least at $300 \mathrm{mV}$ over at minimum 6 blocks with 10 scans each.

\section{Results and Discussion}

The study of textiles probably goes as far back as to the first Egyptian antiquarians (Good, 2001). Today, archaeological textiles and textile production in Antiquity can be 
investigated by several means, e.g. by comparative studies, textile tools, written sources, fiber counting/recognition techniques, ${ }^{14} \mathrm{C}$ dating techniques, context analyses, dye analyses, visual quality analyses, weaving techniques, and function analyses. However, one of the most important questions remained unanswered: Where did theses textiles, particularly the raw materials they were made of, originate? Until recently, this question was not possible to answer, but the development of several new methodologies designed to fill this gap, can potentially provide new important information regarding the provenance of an ancient textile's raw material. These methodologies apply the $\mathrm{Sr}$ isotope tracing system as an archeometrical tool and include deep precleaning procedures to ensure the removal of contaminants (Frei et al., 2009a, 2010). This contribution aims at presenting the results of such methodological approaches using ${ }^{87} \mathrm{Sr}{ }^{\beta 6} \mathrm{Sr}$ ratios for an attempt to define the provenance of textiles.

One of the important differences between analyzing Sr isotopic ratios in e.g. tooth enamel and hair (wool) lies in the difference in their Sr concentration (Kohn et al., 1999), as $\mathrm{Sr}$ levels are typically low in non-skeletal tissues. Concentrations of $\mathrm{Sr}$ in teeth enamel and bone tissues range often between $c a$. 50-1000 ppm [Bentley (2006) and references therein]. On the other hand, hair has much lower $\mathrm{Sr}$ concentrations of $c a .0 .05-15 \mathrm{ppm}$ (Frei et al., 2009a). Consequently, the pre-cleaning protocol, the ion chromatographic separation of the
Sr and the final mass spectrometrical analyses are more difficult because they create generally a greater methodological and analytical challenge than those for tooth enamel and bone tissues. Thus, the aim is to recover the bioavailable ${ }^{87} \mathrm{Sr} /{ }^{86} \mathrm{Sr}$ ratios of the textiles fibers in order to potentially pinpoint possible areas of origin for the textiles' raw material. Moreover, the protocols have been developed with the perspective of consuming as little as possible of the material. The protocols are now routinely applied to samples in the order of only 10-20 mg.

The first case study, the unspun wool sample of modern Greenlandic Musk ox, is expected to recover relatively elevated ${ }^{87} \mathrm{Sr} /{ }^{86} \mathrm{Sr}$ ratios of the cleaned material, as the feeding grounds are located on very old rocks of an Archaean terrain in Western Greenland. This area is predominantly composed of Archaean gneisses and granitoids (Figure 1) therefore characterised by high ${ }^{87} \mathrm{Sr}{ }^{86} \mathrm{Sr}$ ratios. As the unspun wool fibers had not been dyed, the decontamination procedure followed was the one for undyed wool (Frei et al., 2009a).

Samples from the second case study, the archaeological textiles from the pre-Roman Krogens Mølle site were chosen because previous studies of sample material from this site have shown that at least three other samples had been dyed in antiquity with luteolin and/or indigotin dyestuffs (Vanden Berghe et al., 2009). The samples studied herein were expected to be dyed as well and the pre-cleaning procedure therefore followed the one described above for wool organic-dyed textiles (Frei et al., 2010).

A total of $9{ }^{87} \mathrm{Sr} /{ }^{86} \mathrm{Sr}$ ratios (leachates/fractions recovered from the pre-treatment steps included) from the five samples studied herein are presented in Table 1 . The ${ }^{87} \mathrm{Sr} /{ }^{86} \mathrm{Sr}$ ratios from the unspun wool sample of the Greenlandic Musk ox yielded the highest ${ }^{87} \mathrm{Sr} /{ }^{86} \mathrm{Sr}$ ratio of all the five samples analysed herein. The Musk ox residual wool has a ${ }^{87} \mathrm{Sr} /{ }^{86} \mathrm{Sr}$ ratio of 0.71419 , a ratio which resulted after the pre-cleaning methods were applied. The pre-cleaning removed a considerable amount of Sr from mass budget calculations it can be seen that a relative amount of $118 \mathrm{ppm}$ from a total relative concentration of $\sim 140 \mathrm{ppm}$ (sum of Sr from $\mathrm{HF}$ and $\mathrm{HCl}$ leachates, and the residual material) was leached away during the decontamination procedures. These calculations do not consider the fraction of Sr which was potentially removed by the deionised water $\left(\mathrm{Milli}^{\mathrm{TM}}\right)$ rinsing steps interspersed after the acid leaching steps. This implies that the concentration of $\mathrm{Sr}$ in the final residue is a maximum concentration. The elevated Sr isotope value of the residual fraction of the Musk ox wool fibers seems only partially to reflect the radiogenic $\mathrm{Sr}$ of the Archaean rocks exposed in the Kangerlussuaq area. Even higher values $\left({ }^{87} \mathrm{Sr} /{ }^{86} \mathrm{Sr}>\sim 0.75\right)$ could be expected in such geologically ancient areas, but the proximity of the grazing area to the fjord shore, and thus to seawater, enabled the potential contamination of the soils by seawaterspray, and thus by relatively unradiogenic $\mathrm{Sr}$

Table 1. Strontium concentrations and isotope ratios of wool.

\begin{tabular}{|c|c|c|c|c|c|}
\hline Sample description & Treatment & Weight (mg) & Sr (ppm) & ${ }^{87} \mathrm{Sr} /{ }^{86} \mathrm{Sr}$ & 2 SE (abs) \\
\hline Greenland Musk ox & HF leach & 77.35 & 93.58 & 0.71382 & 0.00003 \\
\hline Greenland Musk ox & $\mathrm{HCl}$ leach & 77.35 & 25.09 & 0.71389 & 0.00003 \\
\hline Greenland Musk ox & Residue (wool) & 77.35 & 18.50 & 0.71419 & 0.00006 \\
\hline Krogens Mølle D 1310 A (dark yarn) & HF leach & 11.93 & 19.47 & 0.70896 & 0.00006 \\
\hline Krogens Mølle D 1310 A (dark yarn) & $\mathrm{HCl}$ leach & 11.93 & 292.67 & 0.70863 & 0.00004 \\
\hline Krogens Mølle D 1310 A (dark yarn) & Ammonium peroxodisulfate & 11.93 & 20.09 & 0.70894 & 0.00004 \\
\hline Krogens Mølle D 1310 A (dark yarn) & Residue (wool) & 11.93 & 0.23 & 0.71030 & 0.00007 \\
\hline Krogens Mølle D 1310 A (light yarn) & HF leach & 5.50 & 1.46 & 0.70946 & 0.00002 \\
\hline Krogens Mølle D 1310 A (light yarn) & $\mathrm{HCl}$ leach & 5.50 & 1.47 & 0.70988 & 0.00004 \\
\hline Krogens Mølle D 1310 A (light yarn) & Ammonium peroxodisulfate & 5.50 & 1.44 & 0.70946 & 0.00002 \\
\hline Krogens Mølle D 1310 A (light yarn) & Residue (wool) & 5.50 & 0.03 & 0.71195 & 0.00003 \\
\hline Krogens Mølle D 1310 D & HF leach & 14.25 & 13.78 & 0.70998 & 0.00004 \\
\hline Krogens Mølle D 1310 D & $\mathrm{HCl}$ leach & 14.25 & 9.07 & 0.71121 & 0.00005 \\
\hline Krogens Mølle D 1310 D & Ammonium peroxodisulfate & 14.25 & 7.29 & 0.70920 & 0.00005 \\
\hline Krogens Mølle D 1310 D & Residue (wool) & 14.25 & 2.07 & 0.71013 & 0.00005 \\
\hline Krogens Mølle D $1310 \mathrm{~J}$ & HF leach & 13.29 & 22.85 & 0.70822 & 0.00006 \\
\hline Krogens Mølle D $1310 \mathrm{~J}$ & $\mathrm{HCl}$ leach & 13.29 & 197.58 & 0.70816 & 0.00004 \\
\hline Krogens Mølle D $1310 \mathrm{~J}$ & Ammonium peroxodisulfate & 13.29 & 37.82 & 0.70811 & 0.00004 \\
\hline Krogens Mølle D $1310 \mathrm{~J}$ & Residue (wool) & 13.29 & 3.44 & 0.70878 & 0.00005 \\
\hline
\end{tabular}

SE, Standar error; $\mathrm{HF}$ leach, hydrofluoric leach; $\mathrm{HCl}$ acid leach, hydrochloric acid leach. 
with a ${ }^{87} \mathrm{Sr} /{ }^{\beta 6} \mathrm{Sr}$ ratio of $\sim 0.7092$. Such seawater-spray contamination has been recognised and discussed in previous studies (Frei et al., 2009a; Price and Gestsdottir, 2006). It seems likely therefore that the composition of bioavailable $\mathrm{Sr}$ in the grazing area of the Musk ox is substantially depressed/lowered by seawater spray contamination.

Results of the four Krogens Mølle samples studied herein are also presented in Table 1. Two samples belong to the same textile piece, D 1310 A. One sample was taken from the darker yarn and one from the lighter yarn, with the purpose of investigating potential differences in the Sr isotope composition of the two yarns. The darker yarn yielded a residual ${ }^{87} \mathrm{Sr} /{ }^{86} \mathrm{Sr}$ ratio of 0.71030 which can be considered as local to the site if one uses the baseline established for Denmark which constrains local composition to a range between ${ }^{87} \mathrm{Sr} /{ }^{86} \mathrm{Sr}=\sim 0.708-0.711$ (Frei and Frei, 2011; Frei and Price, 2012). On the other hand, the lighter wool yarn yielded a more radiogenic ${ }^{87} \mathrm{Sr} /{ }^{86} \mathrm{Sr}$ ratio of 0.71195 . Using the same dis- crimination as above, this yarn sample seems to indicate a non-local provenance as its $\mathrm{Sr}$ isotope value falls outside the range typical of Danish bio-available Sr. Bornholm excluded Similar recent investigations have shown that another well preserved pre-Roman Iron Age textile, the Huldremose II find, from another peat bog site in Jutland, is composed of yarn from both local and non-local provenance (Frei et al., 2009b).

The other two yarn samples from two different textile pieces, D $1310 \mathrm{D}$ and D $1310 \mathrm{~J}$, have ${ }^{87} \mathrm{Sr} /{ }^{86} \mathrm{Sr}$ ratios of 0.71013 and 0.70878 respectively. Thus, both $\mathrm{Sr}$ isotopic values fall within the isotopic range of bio-available $\mathrm{Sr}$ from Denmark established by (Frei and Frei, 2011; Frei and Price, 2012) and thus can be considered as local. Nevertheless, the significant difference in their $\mathrm{Sr}$ isotopic composition implies that they do not seem to come from the same area. Interestingly, the yarn sample D $1310 \mathrm{~J}$, which has the lowest $\mathrm{Sr}$ isotope ratio reported in this study, could come from a site to south of the Krogens Mølle area, where sim- ilar Sr isotope values of surface water have been reported (Frei and Frei, 2011). In gener$\mathrm{al}$, the $\mathrm{Sr}$ isotopic values measured on the four yarn samples of wool textiles from the Krogens Mølle site seem to point to different, but distinctive localities. Two of the localities seem to be local and constrained to Jutland (Denmark), the third one seems to be nonlocal to Denmark (Bornholm excluded). The two yarns with significantly different, but still Danish signatures could potentially be explained by differences in the Jutlandic bioavailable signatures. The less radiogenic ${ }^{87} \mathrm{Sr} /{ }^{86} \mathrm{Sr}$ ratio of 0.70878 for sample D $1310 \mathrm{~J}$ could potentially indicate an area south of the Krogens Mølle site and in the vicinity of the Limfjord, where Eocene ash layers apparently have the effect of lowering of the bio-available signal of Sr (Frei and Frei, 2011). It is however, too premature to elaborate on the provenance of the textile D $1310 \mathrm{~A}$, which has a nonlocal (non-Danish) signature. One possibility would be to deduce such values from the southernmost part of Sweden (Skåne) or from some regions of northern Germany, as similar values have been reported for mineral waters from these regions (Voerkelius et al., 2010).

\section{Conclusions}

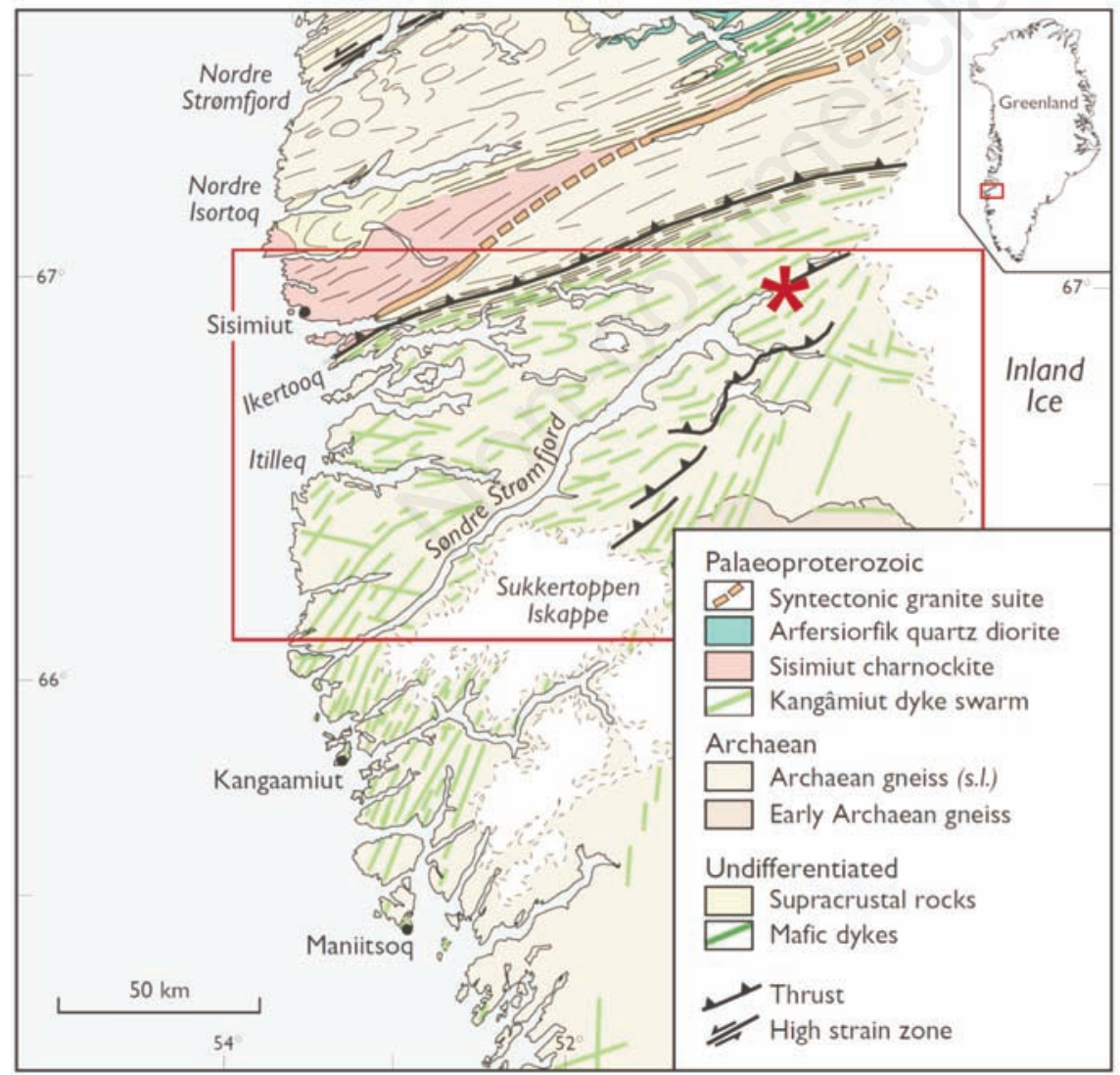

Figure 1. Geological map covering the region of Kangerlussuaq/Søndrestrømfjord in southwest Greenland, modified after Jensen et al. (2002). The red star shows the location where the wool sample was collected, situated near Kangerlussuaq.
The study presented herein shows the importance of removing dust, and dyestuff of ancient wool textiles prior $\mathrm{Sr}$ isotope analyses for provenance investigations. Modern unspun wool from Musk ox that grassed in an area dominated by Archaean gneisses was expected to show a strongly radiogenic ${ }^{87} \mathrm{Sr} /{ }^{86} \mathrm{Sr}$ composition that would mirror the ancienity of the terrain. Our analyses showed that this wool has indeed an elevated ${ }^{87} \mathrm{Sr} /{ }^{86} \mathrm{Sr}$ ratio of $\sim 0.714$, but lowering of this ratio by on-site contamination of the grazing area by seawater-spray might explain a depression of the bio-available fraction of the soil in this area, which then translates into the food chain of the Musk ox.

The four ancient wool yarn samples belonging to textiles from a pre-Roman Iron Age site in the northern part of the Danish peninsula of Jutland, yielded significantly lower values than the one recovered for the Musk ox wool. Three samples seem to be local to Jutland, but probably from two different sites; one near the Krogens Mølle area (two threads) and one from an area more towards the south, where less radiogenic $\mathrm{Sr}$ isotope values of bioavailable fractions have been reported and mapped. The last textile sample falls out of the $\mathrm{Sr}$ isotopic range characterising bio-available compositions typical of Denmark (Bornholm excluded) and thus can be interpreted as nonlocal. 


\section{References}

Andersson Strand E, Frei KM, Gleba M, Mannering U, Nosch ML, Skals I, 2010. Old textiles new possibilities. Eur J Archaeol 13:149-73.

Barber EJW, 1991. Prehistoric textiles. Princeton University Press, New Jersey, 471 pp.

Bender Jørgensen L, 1986. [Prehistoric Scandinavian textiles]. [Book in Danish]. Det Kongelige Nordiske Oldskriftselskab, Copenhagen.

Benson LV, Hattori EM, Taylor HE, Poulson SR, Jolie EA, 2006. Isotope sourcing of prehistoric willow and tule textiles recovered from western Great Basin rock shelters and caves - proof of concept. J Archaeol Sci 33:1588-99.

Bentley RA, 2006. Strontium isotopes from the earth to the archaeological skeleton: a review. J Archaeol Method Th 13:135-87.

Broholm HC, Hald M, 1940. Costumes of the Bronze Age in Denmark. A. Busck ed., Copenhagen.

Brøndsted J, 1960. [Danmarks Oldtid; Jernalderen]. [Book in Danish]. Gyldendalske Boghandel Nordisk Forlag ed., Copenhagen.

Ericson JE, 1985. Strontium isotope characterization in the study of prehistoric human ecology. J Hum Evol 14:503-14.

Evans JA, Chenery CA, Fitzpatrick AP, 2006. Bronze age childhood migration of individuals near Stonehenge, revealed by strontium and oxygen isotope tooth enamel analysis. Archaeometry 48:309-21.

Evans JA, Montgomery J, Wildman G, Bouton $\mathrm{N}, 2010$. Spatial variations in biosphere ${ }^{87} \mathrm{Sr} /{ }^{86} \mathrm{Sr}$ in Britain. J Geol Soc London 167:1-4.

Frei KM, 2009. New constraints on the origin of the Gerum cloak's raw material. Journal of Swedish Antiquarian Research 4:313-5.

Frei KM, Frei R, 2011. The geographic distribution of strontium isotopes in Danish surface waters: a base for provenance studies in archaeology, hydrology and agriculture. Appl Geochem 26:326-40.

Frei KM, Frei R, Mannering U, Gleba M, Nosch ML, Lyngstrøm H, 2009a. Provenance of ancient textiles: a pilot study evaluating the strontium isotope system in wool. Archaeometry 51:252-76.

Frei KM, Price TD, 2012. Strontium isotopes and human mobility in prehistoric Denmark. Archaeol Anthropol Sci 4:10314.

Frei KM, Skals I, Gleba M, Lyngstrøm H, 2009b. The Huldremose Iron Age textiles, Denmark: an attempt to define their provenance applying the Strontium isotope system. J Archaeol Sci 36:1965-71.

Frei KM, Vanden Berghe I, Frei R, Mannering U, Lyngstrøm H, 2010. Removal of organic dyes from wool - implications for ancient textiles provenance studies. J Archaeol Sci $37: 2136-45$.

Gleba M, 2008. Textile production in PreRoman Italy. Oxbow Books, Oxford.

Good I, 2001. Archaeological textiles: a review of current research. Annu Rev Anthropol 30:209-26.

Graustein WC, 1989. ${ }^{87} \mathrm{Sr} / 86 \mathrm{Sr}$ ratios measure the sources and flow of strontium in terrestrial ecosystems. In: P.W. Rundel, J.R. Ehleringer, K.A. Nagy (eds.) Stable isotopes in ecological research. Springer, New York, pp 491-512.

Grupe G, Price TD, Schroter P, Sollner F, Johnson CM, Beard BL, 1997. Mobility of Bell Beaker people revealed by strontium isotope ratios of tooth and bone: a study of southern Bavarian skeletal remains. Appl Geochem 12:517-25.

Hald M, 1980. Ancient Danish textiles from bogs and burials. National Museum of Denmark Publications, Copenhagen.

Horwitz EP, Chiarizia R, Dietz RW, 1992. A novel strontium-selective extraction chromatographic resin. Solvent Extr Ion Exc 10:313-36.

Jensen SM, Hansen H, Secher K, Seenfelt A, Schjøth F, Rasmussen TM, 2002. Kimberlites and other ultramafic alkaline rocks in the Sisimiut-Kangerlussuaq region, southern West Greenland. Geology of Greenland Survey Bulletin 191:57-66.

Knudson KJ, Tung TA, Nystrom KC, Price TD, Fullagar PD, 2005. The origin of the Juch'uypampa Cave mummies: strontium isotope analysis of archaeological human remains from Bolivia. J Archaeol Sci 32:903-13.

Kohn MJ, Schoeninger MJ, Barker WW, 1999. Altered states: effects of diagenesis on fossil tooth chemistry. Geochim Cosmochim Ac 63:2737-47.

Mannering U, Possnert G, Heinemeier J, Gleba M, 2010. Dating Danish textiles and skins from bog finds by means of C-14 AMS. J
Archaeol Sci 37:261-8.

Montgomery J, 2010. Passports from the past: investigating human dispersals using strontium isotope analysis of tooth enamel. Ann Hum Biol 37:325-46.

Montgomery J, Evans JA, Neighbour T, 2003. Sr isotope evidence for population movement within the Hebridean Norse community of NW Scotland. J Geol Soc London 160:64953.

Price TD, Burton JH, 2011. An introduction to archaeological chemistry. Springer, New York.

Price TD, Burton JH, Bentley RA, 2002. The characterization of biologically available strontium isotope ratios for the study of prehistoric migration. Archaeometry 44:117-35.

Price TD, Burton JH, Sharer RJ, Buikstra JE, Wright LE, Traxler LP, Miller KA, 2010. Kings and commoners at Copan: Isotopic evidence for origins and movement in the Classic Maya period. J Anthropol Archaeol 29:15-32.

Price TD, Frei KM, Dobat AS, Lynnerup N, Bennike P, 2011. Who was in Harold Bluetooth's army? Strontium isotope investigation of the cementery at the Viking Age fortress at Trelleborg, Denmark. Antiquity 85:476-89.

Price TD, Gestsdottir H, 2006. The first settlers of Iceland: an isotopic approach to colonisation. Antiquity 80:130-44.

Price TD, Grupe G, Schroter P, 1998. Migration in the Bell Beaker period of central Europe. Antiquity 72:405-11.

Vanden Berghe I, Gleba G, Mannering U, 2009. Towards the identification of dyestuffs in Early Age Scandinavian peat bog textiles. J Archaeol Sci 36:1910-21.

Voerkelius S, Gesine DL, Rummel S, Quétel CR, Heiss G, Baxter M, Brach-Papa C, Deters-Itzelsberger P, Hoelzl S, Hoogewerff $\mathrm{J}$, Ponzevera E, Van Bocxstaele M, Ueckermann H, 2010. Strontium isotopic signatures of natural mineral waters, the reference to a simple geological map and its potential for authentication of food. Food Chemistry 118:933-40.

Von Carnap-Bornheim C, Nosch M-L, Grupe G, Mekota A-M, Schweissing MM, 2007. Stable strontium isotopic ratios from archaeological organic remains from the Thorsberg peat bog. Rapid Commun Mass Sp 21:1541-5. 